\title{
The Pentagon's Gay Ban Is Not Based on Military Necessity
}

\author{
Aaron Belkin, $\mathrm{PhD}$ \\ University of California, Santa Barbara
}

\begin{abstract}
When President Bill Clinton attempted to lift the U.S. military's ban on gay and lesbian soldiers, Congress reacted by enacting a law that prohibits known homosexuals from serving in the U.S. armed forces. The official justification for the new policy is the unit cohesion rationale, the notion that if known gays and lesbians were allowed to serve, unit cohesion, performance, readiness and morale would decline. The thesis of this paper is that the evidence that advocates of discrimination invoke to support the plausibility of the unit cohesion rationale does not constitute scientifically valid data. This paper was delivered originally as a lecture at the Commonwealth Club of California and broadcast subsequently on National Public Radio. [Article copies available for a fee from The Haworth Document Delivery Service: 1-800-342-9678. E-mail address: <getinfo@haworthpressinc.com> Website: $<$ http://www.HaworthPress.com> (C) 2001 by The Haworth Press, Inc. All rights reserved.]
\end{abstract}

KEYWORDS. Don't Ask, Don't Tell, gays and lesbians in the military, unit cohesion rationale, gay ban

As I first started to delve into the issue of gays and lesbians in the military several years ago, I became familiar with the work of the Servicemembers

Aaron Belkin is Director of the Center for the Study of Sexual Minorities in the Military and Assistant Professor, Department of Political Science, University of California, Santa Barbara, CA 93106-9420 (E-mail: belkin@sscf.ucsb.edu).

This report was presented as a lecture to the Commonwealth Club of California on March 2, 2000 and broadcast subsequently on National Public Radio.

The author thanks Gloria Duffy, the Compton Foundation, the R. Gwin Follis Foundation, the Gill Foundation, the Evelyn and Walter Haas Jr. Fund, and the Uncommon Legacy Foundation for their support.

Journal of Homosexuality, Vol. 41(1) 2001

(C) 2001 by The Haworth Press, Inc. All rights reserved. 
Legal Defense Network in Washington. The Servicemembers Legal Defense Network is in the business of reporting abuses of gays and lesbians in the military, abuses that are tolerated by military officials and that include a widespread pattern of violent harassment such as beatings and rapes (Sobel, Westcott, Benecke \& Osburn, 2000).

And as I read about these events, I wondered what had happened to the policy known as "Don't-Ask, Don't-Tell." I thought that the President and the Congress and the Pentagon had reached a compromise that allowed gay people to serve honorably in the military and to be left alone as long as they did not reveal their sexual orientation (Halley, 1999, pp. 19-26). And as I learned more and more about the evidence, I became more and more appalled. And I came to realize that literally, there is no intellectually honest position from which to argue that lifting the ban on gays and lesbians would harm the military.

I realize that such an extreme statement may cause discomfort given that our entire political system is based on compromise and gradual reform. However, whether one is a Republican or a Democrat, whether one likes gay people or dislikes them, whether one is a donor to Bob Jones University or not, I want to claim that there is no possibility for making an argument based on evidence that lifting the ban would harm the military.

Before walking through the evidence, I would like to review the basics of the military ban, the policy known as "Don't-ask, Don't-Tell." What is this policy that the Pentagon has violated over 5,000 times in the last few years alone? "Don't-Ask, Don't-Tell" is a policy that says that gays and lesbians are allowed to serve in the military as long as they do not reveal their sexual orientation. The military imagines that coming out of the closet is like spreading contagious fluid, almost like the AIDS virus (Butler, 1997, p. 116). For a soldier to admit that he or she is gay, to say the words "I am gay," is so bad that other people in the soldier's unit would be socially infected and the unit no longer would be able to function. Hence the compromise: we will not ask you if you are gay, but you are not allowed to tell us if you are gay. Don'tAsk, Don't-Tell.

Is "Don't-Ask, Don't-Tell" reformable? Recently there have been initiatives to try to improve the implementation of this policy, to stop harassment, to stop gay bashing, to stop the beatings of gay people in the military ("Harassment of Gays," 2000). But I like to think about the reformability of "Don't-Ask, Don't-Tell" in terms of a poll tax. Consider a poll tax that charges some group of people, say Chinese people, ten dollars to vote. One could introduce a reform initiative and say "well, we are going to reform our poll tax, and we are going to charge only five dollars for Chinese people to vote." But a poll tax is a poll tax is a poll tax. And the same is true with “Don't-Ask, Don't-Tell." Why? Because as long as gay and lesbian people 
are not allowed to admit who they are, there is no way for them to complain about harassment. They cannot complain about harassment, of course, because doing so could get them kicked out of the military for being gay. And the fact that they are not allowed to complain about harassment provides a green light to anyone thinking of tormenting them or beating them.

What is the justification behind "Don't-Ask, Don't-Tell"? One might guess that this policy has ten justifications or five or three. But in fact, the official policy as articulated in congressional statute and Pentagon implementing regulations specifies only one official rationale for the "Don't-Ask, Don't-Tell" policy. And that rationale is called the "unit cohesion" rationale. The unit cohesion rationale is the idea that if gays and lesbians revealed their sexual orientation, then units no longer would be able to function. Heterosexual soldiers hate gays and lesbians and cannot trust them with their lives and unit performance and cohesion would fall apart.

Consider a 60 Minutes report that was broadcast in December, 1999. In the broadcast, Lieutenant Colonel Robert McGinnis, who also happens to be a staff member of the Family Research Council, provides a very clear articulation of the unit cohesion rationale (Don't Ask, 1999; U.S. Congress, 1993). He says:

Cohesion is the glue that holds small units together. In ranger school we would wrap a poncho liner around us when we were cold. So you're sharing body heat. If there is any perception of inappropriate behavior that you think might result from that, you have to have total trust that not only are they going to pull your wounded body off the battlefield but that they won't do any thing untoward.

Ed Bradley follows, "so if you were under that poncho sharing body heat with that gay soldier, that would make you uncomfortable?" McGinnis responds "It definitely would make me uncomfortable."

This is the rationale for the gay ban. And this rationale depends on a funny assumption. It depends on the assumption that most people in the military, most days of their lives, spend time in foxholes. Now we could start to pick apart the unit cohesion rationale by noting that of the 400,000 or so people in the Air Force, I am not aware of a single one who spends any time in a foxhole. In fact, most people in the military work together in the same way the people of corporate America work together in offices. Given that much if not most of the military looks like an office, and given that gays and heterosexuals can work together at Microsoft and Boeing and the Marriott Corporation, one starts to wonder why they cannot work together in the military.

People who support the gay ban provide two pieces of evidence to show that known gays and lesbians undermine military performance. The first kind of evidence they cite is anecdotal evidence. And most anecdotes take the 
following form: "Well, I served for twenty years in the military, and I was in a unit once where we had a gay guy and something bad happened" (U.S. Senate, 1993). And that something bad might have been that the gay person did something bad, or something bad was done to the gay person, or the gay person had sex when he or she was not supposed to have sex. It is anecdotal evidence, and the specific content of the anecdote does not matter. The critical point to consider is that anecdotes are not a sound basis for policy. If we did base policy on anecdotes, certainly we could come up with anecdotes of chubby people who have caused problems in the military and left-handed people and Chinese people and African American people and heterosexual people who have caused problems. But anecdotes are not a sound foundation for law because official policies should not be based on inferring the attributes of an individual from stereotypes about his or her class. And even if one could identify thousands of anecdotes about gay people causing problems, that would not mean that any particular gay person is problematic. Gays and lesbians should be judged by their own record in the same way that everyone else is judged on their individual record.

In addition, anecdotes do not constitute scientifically valid evidence. The question is not whether one or ten or one hundred or even one thousand gays and lesbians have undermined their units' cohesion. Rather, the question is whether on average gays and lesbians tend to undermine cohesion. For every anecdote that advocates of discrimination use to show that gays and lesbians undermine cohesion, others can be identified to show that they do not undermine cohesion. So the anecdotal evidence that supporters of discrimination cite is not something that can be taken seriously.

However, there is another type of evidence that advocates of discrimination cite to support the unit cohesion rationale. This second piece of evidence consists of statistical surveys that show that heterosexual soldiers do not like gay soldiers (Miller \& Williams, 1999). And therefore an equation is made in which straight soldiers' dislike of gay soldiers is said to be the same as unit cohesion falling apart.

There are three reasons why surveys do not count as evidence for the unit cohesion rationale. First, dislike has no impact on organizational performance. I am not citing one study or ten studies here. Literally there are hundreds of studies from sports theory, organization theory and military theory that show that whether group members like each other has no bearing on how well organizations perform (Kier, 1998). One can think of sports teams in which the quarterback and the wide receiver hate each other. Whether or not those teams do well has nothing to do with hatred. Performance depends, rather, on whether team members are committed to the same goals.

Indeed, in the military itself one can point to numerous groups whose members have been at each other's throats. Yet the armed forces have served 
as a socialization engine that lets them serve together. Imagine someone from Bob Jones University in a unit with someone who is in an interracial romantic relationship. Those people would learn to work together because dislike has no impact on organizational performance. Again, that is the result of hundreds of studies summarized most recently in the Harvard University journal International Security (Kier, 1998). It is not a gay journal. It is not even a liberal journal. It is the most prestigious journal in the field of international security and it summarized these hundreds of studies.

The second reason why these statistical surveys do not support the idea that the presence of known gays in the military would undermine performance or cohesion is that bigoted attitudes are not the same as bigoted behavior. As described in the well-known Lapiere study (1934), a white man toured the country with two Chinese people and logged over 10,000 miles on his car. They visited 251 hotels and restaurants and trailer parks. And before arriving at each establishment, Lapiere called and said "I have very important Chinese visitors with me. Would you mind if we stay in your hotel or would you mind if we eat in your restaurant?" Every single establishment said, "No, we do not accept Chinese people in our restaurant or our hotel." Then Lapiere and his Chinese friends visited the establishment and 250 out of 251 of them served the Chinese couple without a problem. The evidence shows that bigoted attitudes are not the same as bigoted behavior.

One could claim that the Lapiere study has nothing to do with homosexuality. But then I would point to an entire literature that has been produced in the last fifteen years that shows that even when people dislike homosexuals, as soon as they have contact with an actual gay or lesbian person, in most cases the dislike goes away, and in all cases people are able to work together (Herek \& Capitanio, 1996).

One could respond that those studies do not reflect the military. In that case, I would point to a study of the Canadian military that my research center sponsored. In 1985, the Defense Department in Canada did a survey of 6,500 soldiers. At the time, Canada prohibited known gays and lesbians from serving in the military. And of those 6,500 soldiers, $62 \%$ said they would not shower with a gay person, that they would not bunk with a gay person, and that they would not undress with a gay person. Now fast-forward to 1992. Canada lifted its gay ban. Now fast-forward to 1995, when the Canadian military did another survey and found no problems whatsoever with discipline. The Canadians found that the majority of soldiers were satisfied with the fact that gays could serve openly (Belkin \& McNichol, 2000; Zuliani, 1986; Wenek, 1995). The bottom line is that bigoted attitudes are not the same as bigoted behavior. Even though supporters of discrimination can point to surveys that show that heterosexual soldiers do not like gays and lesbians, this does not mean that known gays undermine unit cohesion. 
The third reason why statistical surveys are not evidence is that heterosexual soldiers' dislike of gays and lesbians is less extreme than supporters of the gay ban suggest. According to people who oppose lifting the ban, heterosexuals in the armed forces hate gays and lesbians. A close reading of the evidence shows that this is not true. From 1992 to 1998, the percentage of U.S. Army men who strongly oppose gays and lesbians in the military dropped from $67 \%$ to just $36 \%$. The percentage of Army women who strongly oppose gays and lesbians in the military dropped from 32\% to 16\% (Miller, 1994; Kier, 1999, p. 196).

Armando Estrada, a psychologist at the University of Texas, administered a feeling thermometer to a sample of male U.S. marines in a 1999 study (Estrada \& Weiss, 1999). On this particular feeling thermometer, a score of zero reflects total hatred of gay people and a score of one hundred signals complete acceptance. Estrada found that the Marines' average result on the feeling thermometer was 47.52 . The specific number is not important but it is meaningful that the average score fell roughly in the middle of the scale, thus indicating mild dislike rather than widespread hatred. Some people in the military hate gays and lesbians but on average one finds mild dislike. Another finding from the Estrada study is that $47 \%$ of male Marines say that if there is a draft, gays should be drafted just like everybody else. If gays should be drafted like everybody else, then how can it be true that they undermine unit cohesion when we have a volunteer military?

So, for two reasons I would argue that there is no evidence to support the unit cohesion rationale. Neither statistical surveys nor anecdotes show that gays and lesbians undermine military cohesion.

Before addressing the evidence on the other side of the coin that shows that gays can serve in military organizations without causing problems, it makes sense to consider whether or not the gay ban has any costs. I would argue that there are at least four costs associated with "Don't-Ask, Don'tTell."

First, the policy is expensive and the most conservative estimate of the cost of kicking out gay people from the military is that over the last five years, the Pentagon has spent $\$ 130$ million dollars in lost training. And over the course of the Cold War, the U.S. spent about $\$ 500$ million dollars kicking out gay and lesbian people (Shilts, 1993, p. 476; Sobel, Westcott, Benecke \& Osburn, 2000, p. 74). These are conservative figures because they do not include soldiers who were forced to resign and they do not include the cost of investigations. They include only the cost of the lost training of people who were fired.

The second problem associated with the gay ban is brain drain and talent loss. The U.S. military fires about one thousand people each year for being gay. Many of the soldiers who have been fired or who have left the military as 
a result of the gay ban are very talented people such as Andrea Hollen, a Rhodes scholar. These are people who should be using their talents to serve their country as they choose and who enter the private sector and pursue successful careers.

Ruined lives and psychological casualties constitute the third problem with this policy. The tactics and techniques of military investigators leave psychological scars on their victims that last for years. To take one of many examples, consider the case of Loren Loomis who was fired from the military just five days short of his twenty-year eligibility for retirement (Egan, 1998, p. 30).

A fourth and final problem with this policy is that it leads to violence against women. During a debate on Catholic Family Radio, I faced an extreme right-wing pundit who claimed that the military ban does not lead to violence against women and that complaints about this issue come from "a few whining lesbians." Perhaps this pundit was not aware of a recent Veterans Administration study that found that $23 \%$ of women in the military experience actual physical violence or the threat of physical violence during their military careers. While the Pentagon has not released recent data, figures show that between 1987 and 1991 there were 484 rapes of women serving in the military (Chema, 1993).

What does this pattern of violence against women have to do with the gay ban? The link is that in many cases women cannot report their harassers and even their rapists because if they do they can be investigated for homosexuality. Perpetrators know that women are unlikely to report them and this knowledge serves as a green light for would-be abusers. For example, after Canada lifted its gay and lesbian ban, sexual harassment against women dropped $46 \%$ (Belkin \& McNichol, 2000, pp. 25-26; Beneck \& Dodge, 1990). While there were several reasons why sexual harassment dropped $46 \%$, one factor was that women were free to report their harassers, thus deterring potential perpetrators.

A final point to consider is whether any evidence shows that gays and lesbians can serve openly without undermining cohesion. I would like to present six pieces of evidence that show that known gays and lesbians can serve in the military without causing any problems.

First, known gays and lesbians already do serve openly in the American military without causing problems. In a recent debate on National Public Radio, Charles Moskos, the architect of "Don't-Ask, Don't-Tell," said that "there are no open gays in the U.S. military." If you consult the University of Missouri-Kansas City Law Review, Fall 1995, however, you will find an eight-page list of gays who have served openly in the military (Osburn, 1995, pp. 215-223). And, a recent study found that $39.1 \%$ of enlisted naval personnel know a gay sailor (Bicknell, 2000). 
Second, gays and lesbians serve openly in police departments without causing problems. San Diego is a conservative city but the gay-lesbian liaison officer of the San Diego police department reports that about fifty known gays and lesbians serve on the force. Police work requires daily exposure to violence, and unit cohesion and trust of fellow officers are very important. And yet the many American police departments that have lifted their gay bans continue to function properly (Koegel, 1996).

Advocates of military discrimination note that police officers do not live or shower in shared quarters. While this is true, they should consider a third piece of evidence that gays can serve openly without causing problems. Gays and lesbians are allowed to serve openly in fire departments and this has not caused a problem for unit cohesion. They are allowed to live in fire houses and to take showers with their peers in Seattle, Chicago, New York and elsewhere (Koegel, 1996).

A fourth piece of evidence that gays and lesbians can serve openly without causing any detriment to unit cohesion is that they are allowed to serve in the CIA, in the FBI and in the Secret Service on President Clinton's security detail. It is not possible to claim that the President's security detail does not require unit cohesion.

The fifth piece of evidence is that gays and lesbians are allowed to serve openly in foreign militaries. Every original NATO country except Turkey allows known gays and lesbians to serve in the armed forces ("Gay Troops," 2000). People who support discrimination respond that there are variations in policy, that in some countries gays and lesbians cannot be promoted past a certain level and that in others they are denied security clearances. These variations do not matter. The fact is that despite the variations, known gays and lesbians are allowed to serve and they do not undermine unit cohesion. Another response is that cultural differences underscore the irrelevance of foreign military experiences for determining whether known gays and lesbians would undermine cohesion in the U.S. armed forces. While no two cultures are the same, twenty-three different countries allow known gays and lesbians to serve. Given that there is no evidence that any of these countries have suffered a decline in military performance despite their cultural differences, one has to wonder why a more tolerant policy would fail in the United States. Advocates of discrimination respond that most people do not come out of the closet in foreign militaries. If gay soldiers prefer to serve on a discreet basis, however, then there is even less reason to fear lifting the ban. Advocates of discrimination seem to assume that there is something different about American gays and lesbians that would make them disclose their sexual orientation at a higher rate than gays and lesbians in other militaries.

After Canada lifted its gay ban in 1992, Britain sent an investigative team to Canada to study the effects of the new policy. At the time, Britain had not 
yet lifted its ban and the British team was looking for evidence to show that the new Canadian policy was a failure. After they visited the Canadian forces, however, the British investigators changed their minds because they saw that lifting a gay ban does not undermine military performance (Belkin \& McNichol, 2000, p. 29).

The sixth and final piece of evidence that gays and lesbians can serve openly without causing problems involves American wartime experience. The rate of discharges of gays and lesbians in the American military always declines during wartime. The World War II rate of discharge was ten times lower that the post-war rate. During the Korean and Vietnam Wars, the Pentagon kicked out about half as many gays and lesbians as was the case during peacetime. During the Persian Gulf Crisis, the Pentagon issued a stop-loss order that directed commanders to refrain from firing gays and lesbians. General Bill Nash, who is against letting known gays and lesbians serve in the military, admitted on National Public Radio that when he was in Bosnia, he did not have time to kick several known gays out of his unit.

If gays and lesbians can serve during wartime, and indeed if the Pentagon tries to make them serve during wartime because it wants more bodies available for service, how can one claim that gays undermine cohesion in peacetime? Advocates of military discrimination say that the Pentagon reduces gay discharges during wartime to prevent straight soldiers from trying to escape service by pretending to be homosexual. If military leaders are worried about straight people trying to get out of the military during wartime by pretending to be gay, however, they should lift the gay ban.

Recall that according to the unit cohesion rationale, known gays make it impossible for their units to survive in combat. Let us take the most conservative estimate of the number of gay people in the military. Let us say that $2 \%$ of the American military consists of gay soldiers. This is a conservative estimate given that $3.5 \%$ of the Canadian military is gay. But let us say that only $2 \%$ of the U.S. military is gay or lesbian. That would mean that there are 30,000 gays and lesbians serving. Now let us say that just $10 \%$ of these soldiers are known by their peers to be gay and that the other $90 \%$ remain in the closet. Again, this is a conservative estimate because it is difficult for soldiers who share quarters, who do not have wedding rings, and who do not discuss romantic partners to hide sexual orientation. And, recall that $39.1 \%$ of enlisted naval personnel know a gay sailor. So let us just say conservatively that $10 \%$ or 3,000 people in the military are known by their peers to be gay. According to the Pentagon's own logic, each one of these 3,000 soldiers undermines his or her unit's ability to survive. If the Chairman of the Joint Chiefs of Staff believed the unit cohesion rationale, he would kick these 3,000 known gays and lesbians out of the military during wartime to prevent them from destroying their units. When wars occur, however, the Pentagon 
retains gay and lesbian soldiers. Do military leaders actually expect us to believe that they are willing to permit 3,000 soldiers to destroy their units in order to prevent straight soldiers from pretending to be homosexual? Clearly, even the Pentagon knows that the unit cohesion rationale is not true.

What are the sources for this evidence? Are these points based on gay propaganda? One source is a 518-page RAND Corporation study of the impact of known gays on fire departments, foreign militaries, and police departments. The RAND study includes a 53-page bibliography and it was written by 30 Ph.D. authors. Other sources include a General Accounting Office study of 1993 and a Harvard University study of 1998. These comprehensive reviews of the literature reach the same conclusion: There is no evidence to show that gays and lesbians undermine cohesion (National Defense Research Institute, 1993; U.S. General Accounting Office, 1993; Kier, 1998; Belkin \& McNichol, 2000).

To conclude, the military's ban on known gay and lesbian soldiers seems to be an instance of willful ignorance, a situation in which powerful people prefer to be blind to evidence (Sedgwick, 1990, pp. 4-8). The policy known as "Don't-Ask, Don't-Tell" is proud of its ignorance and its refusal to see. The media has framed the debate on gays in the military as if there is evidence on both sides of the question, as if there are data on both sides of the issue. One does not have to like gay people or be a liberal, however, to see that the media and the talking heads and the pundits have framed this debate on an assumption that is not true.

General Colin Powell and ex-Senator Sam Nunn and Professor Charles Moskos and the other architects of this policy should answer the following questions: If gays undermine unit cohesion, why are they allowed to serve in Canada without causing problems? Why are there fifty of them serving on the San Diego police department without causing problems? Why are they in the Australian navy? Why are they on the Seattle fire department? Why are they in the Israeli military? Why are they in the U.S. secret service without causing problems? Why are they in the British military without causing problems? The architects of this policy should have the integrity to admit that "Don't-Ask, Don't-Tell" is not based on data. It is not based on military necessity. It is based on prejudice and bigotry and nothing else.

Q: You've made a strong case about the absence of an intellectual basis for the ban, but unfortunately, revealing this won't necessarily change the policy. What are the prospects for a more intellectually sound policy and how hopeful are you about things?

A: I think there are three or four avenues to policy change. Policy could change if the Supreme Court were to rule "Don't-Ask, Don't-Tell" unconstitutional. That's unlikely. Policy could change if we had a Nixon-in-China phenomenon, in other words a President with military credentials and mili- 
tary credibility who came out and said we should allow gays to serve openly. And there is precedent for this. There are conservatives such as the late Senator Barry Goldwater who believed gays could serve openly. So, the second mechanism by which policy could change is if we have a conservative President who speaks on behalf of gays and lesbians. And a third, and I think ultimately more realistic avenue to policy change, is the continuing evolution of public and military opinion. As I mentioned, military opinion is changing so that people in the military, the younger generations and ROTC students, are getting more and more accepting of gays and lesbians. Senior military officers are still $76 \%$ opposed to gays in the military, but junior people are changing (Miller \& Williams, 1999). And public opinion is changing over time. Now $56 \%$ of the public in the latest Harris poll say that gays and lesbians should be able to serve openly (Miller \& Williams, 1999). And I think as more and more evidence about the unit cohesion rationale is brought to light, hopefully through the work of my center and other people, people will continue to realize that the military's rationale for the current discriminatory policy is not based on evidence. So, it's hard to say when this will happen, but I'm hopeful because opinion keeps changing.

Q: Do you see connections between the unit cohesion rationale and the sanctity of marriage rhetoric that is used by proponents of California Proposition 22 on our ballot next Tuesday?

A: I think that both arguments are manifestations of the same phenomenon which is homophobia, bigotry. But they're constructed in different ways. The brilliance, the genius of the unit cohesion rationale is that it is constructed as if it were an argument about military necessity, which of course is different than the arguments about the sanctity of marriage, which have nothing to do with military performance, but ultimately and self-admittedly depend on moral criteria rather than criteria of necessity. So, they're based on the same bundle of ideas but they have different constructions.

Q: What makes your work academic rather than advocacy work?

A: The work that my center sponsors is designed to ask whether gays and lesbians undermine cohesion. So we study foreign militaries. We're studying now the Israeli military, the British military, and if we find that there have been problems, we will absolutely report those problems. But similar to the RAND report, and to the Harvard study and the GAO study, we just haven't found any evidence of problems yet. I should say also, and I won't filibuster because I know there are a lot of questions, there are 145 right-wing think tanks in this country (Covington, 1997, p. 7). They get about 30 million dollars a year. They have had twenty-six years since the Dutch lifted their ban to show in some study that gays in foreign militaries undermine cohesion. What are they doing with all their money? I would challenge them to do a study, a methodologically honest study, of a foreign military and show us that 
discipline has become a problem, that recruitment has dropped, that people are resigning, that performance has declined. They've had twenty-six years. Where are the studies?

Q: You're right about separating gays as different and unable to integrate for the unit cohesion rationale. It sounds like bogus arguments vis-à-vis blacks or Negroes or women. How do we frame the argument to persuade the government, military and general population?

A: It's very interesting, as most of you know, until fairly recently, until the 1940s, the Armed Forces did not let African Americans serve on an equal basis with Whites. And there is a very interesting article that compares the language in the debate over African Americans in the military fifty years ago and the debate over gays in the military in 1993 (Bianco, 1996). And it finds no less than twelve similarities. In the 1940s people said that if Blacks served, then Whites wouldn't take showers with them. Same thing with gays. Black bodies were supposedly diseased. Same with gays. Twelve similarities. That having been said, I think that racism is constructed in a different way than homophobia is, and I think that just because it was possible to convince, well President Truman ordered the military to allow African Americans to serve on a equal basis, that does not mean that homophobia can be disabled in the same way that racism was. I think the best path for disabling homophobia in terms of the military arguments is to keep presenting honest evidence about the fact that the unit cohesion rationale is not based on data.

Q: As a follow-up to your answer, are you at all fearful that any future policy might actually allow for all-gay military units as was the case with Blacks for so long?

A: I think in this country we've learned that separate but equal is not equal, and hopefully enough people have learned that to realize that all-gay units would not be beneficial for gay people or for the military.

Q: How big an issue is "Don't-Ask, Don't-Tell" in the gay community as a whole? Why not reject the military altogether?

A: I face this argument a lot. There are a lot of pacifists in the gay and lesbian community who don't want gay and lesbian young people to serve in the armed forces. I understand the argument, I sympathize with the argument, and I face the indifference again and again and again at fundraisers, at academic conferences. A lot of people in the gay and lesbian community don't care about this issue. Two things I would say. First of all, even if you don't want gay and lesbian kids to serve in the military, that should be by choice. It shouldn't be because they are prohibited by law from serving on an equal basis. So, if you believe in pacifism, I think it is more intellectually honest to support an end to the ban and then to work to persuade kids not to go into the military. The second point is that the military is the largest employer in the United States with 1.5 million active soldiers. When the largest employer in 
the United States sends the message that gays and lesbians should not be treated on an equal basis, that sets a terrible precedent for the civilian sector, and for that reason alone, people in the community should be worried about this policy.

Q: Does your research look into how people's opinions on gays in the military change through time? Do arguments sway the opponents of gays in the military or is their logic immune to rational argument?

A: That's a wonderful question. My sense is that part of the country will never be brought around. When I was on Catholic Family Radio, debating this issue, some of the callers said things like, "You keep quoting all these studies and all this evidence, and that's a very slick and slimy thing to do, but that doesn't say anything about our biblical and moral injunctions against homosexuality." Those people are not sensitive to evidence and they will never, in my opinion, change their minds. That being said, as you look at the change in military opinion over the last six or seven years and you look at the change in public opinion, it's clear that there is a huge and powerful middle section of the public that is sensitive to evidence and that is coming around.

Q: Did the military drive the "Don't-Ask, Don't-Tell" policy which then became policy under the executive branch, or was it the other way around, with the executive branch setting policy with the military following?

A: My interpretation of the events that took place at the beginning of the Clinton administration is that the military forced this policy on the President as a reaction to the President's attempts to lift the gay ban and let gays and lesbians serve on an equal basis. This policy, "Don't-Ask, Don't-Tell," is a micro-step away from the old policy that simply prevented gays and lesbians from serving in the military. This is basically not a reform at all, especially when you look at the way it's been implemented and the fact that the Pentagon has violated its own rules 5,000 times. For example, they're not supposed to ask people if they're gay or lesbian, but officers have done things like say "I won't ask you if you're gay, but if I did what would you say?" It's clear that this policy is not progressive, it's not a reform, it's something that was basically forced on the President by members of Congress and the military, who basically, I would argue, did not tell the truth about the unit cohesion rationale.

Q: Does your study address the bisexual person in the military? Are they treated differently in your studies?

A: That's a fascinating question. I'd actually like to take a moment to dwell on that. Any discriminatory system has to define the targets of discrimination in order to work. Otherwise the system wouldn't work. So in Nazi Germany, the regime had to define a Jewish person before it could start targeting Jews, defined as someone with one-sixteenth Jewish blood. Same is the case with the gay ban. The military has to define who a gay person is. 
Usually in this country we prefer to let people define their own identities however they want. If you want to call yourself a Jew, you do, if you don't, you don't. In this case, the military and the Congress, the state, the government, has a formal definition of what a gay person is. And that is someone who has the propensity to manifest same-sex bodily erotic conduct. Actually, it's someone who a reasonable person would judge has the propensity to engage in future same-sex bodily erotic conduct. That is the definition, and that includes bisexuals, of course. The problem, however, is that that rationale, that definition is so capricious, that it can be administered in incredibly unfair ways by courts. For example, there have been courts that have decided that someone is a lesbian because she attended the Dinah Shore golf tournament. True case. And I would argue that that definition does not map onto real people in real ways. It is incoherent and it is dangerous. Why is it incoherent and why is it dangerous? It's dangerous because, as Janet Halley, Harvard professor, has argued, if that definition is ratified by the Supreme Court, it could be amplified to other state institutions, other government institutions, who would then have their own definition of what a gay person is (Halley, 1996). That's why it's dangerous. It's incoherent, and I think much of the public might not understand this point, but like in life in general, there are many straight people in the military who have gay sex, and there are many gay people in the military who don't have gay sex. And so the correlation between identity and sex depends on the individual. Now we have surveys that show that about $7 \%$ of veterans have had gay sex, but only $5 \%$ of the country at large has had gay sex (Shawver, 1995, p. 198). Now there is a lot of anecdotal evidence in the literature by Steven Zeeland, who wrote four books basically about straight people who occasionally have gay sex in the military $(1993 ; 1995 ; 1996 ; 1999)$. These people don't self-identify as gay. They self-identify as heterosexual. But the state imposes a definition on them that essentializes them, that makes their sexual behavior an essential part of their identity instead of letting them decide for themselves what their identity should be. So, I think the question about bisexuality actually taps into one of the most insidious, driving engines of "Don't-Ask, Don't-Tell" and that is the definition that is required to make discrimination possible.

Q: Recognizing the impact of the "Don't-Ask, Don't-Tell" policy, is there any realistic figure of the percentage of gays and lesbians serving currently in our military?

A: There's a whole literature about how you count members of sexual minority communities (Hertzog, 1996, pp. 9-15) and there are debates about this and it's not possible to do this in the military context because, of course, gays and lesbians can't self-identify. And even in a non-military context where they can self-identify, it's hard to count them largely for the reasons I just mentioned, that identity for people changes over time and it changes 
from person to person. Who is a gay person? Who is bisexual? That being said, we know from the Canadian military which does have open gays and lesbians, that $3.5 \%$ of their force acknowledges being gay or lesbian, in the San Diego police department it's $2.5 \%$, in the general population, depending on what you believe, it's between 2 or $3 \%$ and 7 or $8 \%$. So, it's impossible to specify, but we kind of have ranges.

Q: Does "Don't-Ask, Don't-Tell” by its nature actually encourage blackmail against gays currently in the military, and could this policy actually compromise national security more than an open policy?

A: This policy has a tremendously insidious impact on national security and performance. There is a story of a doctor at Travis Air Force Base, about a military doctor not too far from here. He was gay and he borrowed about $\$ 100,000$ from the military for medical school. It was important for him not to get kicked out. His nurse accidentally administered a dose to a patient that was ten times higher than the dose he prescribed, and she almost killed the patient. The doctor called her on it and said "you almost killed this patient." And she said, "remember, Don't-Ask, Don't-Tell, I'm not going to take the fall for this." This is one of many examples of how not allowing gay and lesbian people to acknowledge who they are undermines performance, accountability, chain of command, national security, because they are always already victims or hostages to the possibility of getting kicked out if they upset their peers in any way.

Q: If men and women in the armed forces do not share living quarters because of the potential for sexual attraction, why shouldn't the same principle apply to gays and lesbians?

A: Exposure in the shower and living quarters is going to be exactly the same after the policy changes as it is now. There are already gays and lesbians in the military who take showers and live in the dorms and bunks and barracks with heterosexual soldiers. No one is calling for men and women to sleep together in military quarters, and if heterosexuals can take showers with gay individuals in police departments, and fire departments, and the YMCA, and sports teams, and foreign militaries and even in the U.S. military, there is no reason why they can't continue taking showers with them after the ban is lifted.

Q: Why is the predominately male military leadership so preoccupied with a fear that a straight person might have to deal with an unwanted romantic overture? Most civilian women ably handle this weekly.

A: Time is short? The answer is homophobia.

\section{REFERENCES}

Belkin, A. \& McNichol, J. (2000). Effects of the 1992 lifting of restrictions on gay and lesbian service in the Canadian Forces: Appraising the evidence. Santa Barbara, CA: Center for the Study of Sexual Minorities in the Military. Available: http://www.gaymilitary.ucsb.edu. (July 22, 2000) 
Benecke, M. M. \& Dodge, K. (1990). Military women in nontraditional job fields: Casualties of the armed forces' war on homosexuals. Harvard Women's Law Journal, 13, 215-250.

Bianco, D. A. (1996). Echoes of prejudice: The debates over race and sexuality in the armed forces. In C. A. Rimmerman (Ed.), Gay rights, military wrongs; Political perspectives on lesbians and gays in the military (pp. 47-70). New York: Garland Publishing, Inc.

Bicknell, Jr., J. W. (2000). Study of naval officers' attitudes toward homosexuals in the military. Monterey, CA: Naval Postgraduate School.

Butler, J. (1997). Contagious word: paranoia and "homosexuality in the military." In Excitable speech: A politics of the performative (pp. 103-126). New York: Routledge.

Chema, J. R. (1993). Arresting "tailhook": The prosecution of sexual harassment in the military. Military Law Review, 140.

Covington, S. (1997). Moving a public policy agenda: The strategic philanthropy of conservative foundations. Washington, DC: National Committee for Responsive Philanthropy.

Don't ask, don't tell. (1999, December 12). Sixty Minutes.

Egan, J. (1998, June 28). Uniform in the closet. New York Times Magazine.

Estrada, A. X. \& Weiss, D. J. (1999). Attitudes of military personnel toward homosexuals. Journal of Homosexuality, 37, 83-97.

Gay troops in Europe. (2000, January 15). New York Times.

Halley, J. E. (1996). The status/conduct distinction in the 1993 revisions to military anti-gay policy. GLQ, 3,159-252.

Halley, J. E. (1999). Don't; A reader's guide to the military's anti-gay policy. Durham: Duke University Press.

Harassment of gays in the military. (2000, March 28). New York Times.

Harris interactive election 2000 study. (2000, January 19-26).

Herek, G. M. \& Capitanio, J. P. (1996). Some of my best friends-Intergroup contact, concealable stigma, and heterosexuals' attitudes toward gay men and lesbians. Personality and Social Psychology Bulletin, 22, 412-424.

Hertzog, M. (1996). The lavender vote. New York: New York University Press.

Kier, E. (1998). Homosexuals in the U.S. military: Open integration and combat effectiveness. International Security, 23, 5-39.

Kier, E. (1999). Rights and fights: Sexual orientation and military effectiveness. International Security, 24, 194-201.

Koegel, P. (1996). Lessons learned from the experience of domestic police and fire departments. In G. M. Herek, J. B. Jobe, \& R. M. Carney (Eds.), Out in force; sexual orientation and the military (pp. 131-153). Chicago: University of Chicago Press.

Lapiere, R. T. (1934). Attitudes versus actions. Social Forces, 13, 230-237.

Miller, L. L. (1994). Fighting for a just cause: Soldiers' attitudes on gays in the military. In W. J. Scott \& S. C. Stanley (Eds.), Gays and lesbians in the military (pp. 69-85). New York: Aldine de Gruyter.

Miller, L. L. \& Williams, J. A. (1999). Combat effectiveness vs. civil rights? U.S. military culture, cohesion, and personnel policies in the 1990s. Paper prepared for 
the Triangle Institute for Security Studies Project on the Gap Between the Military and Civilian Society.

National Defense Research Institute. (1993). Sexual orientation and U.S. military personnel policy: Options and assessment. Santa Monica, CA: RAND.

Osburn, C. D. (1995). A policy in desperate search of a rationale: The military's policy on lesbians, gays, and bisexuals. University of Missouri-Kansas City Law Review, 64, 215-223.

Sedgwick, E. (1990). Epistemology of the closet. Berkeley: University of California Press.

Shawver, L. (1995). And the flag was still there: Straight people, gay people, and sexuality in the U.S. military. New York: Harrington Park Press.

Shilts, R. (1993). Conduct unbecoming; Gays and lesbians in the U.S. military. New York: Fawcett Columbine.

Sobel, S. L., Westcott, K. S., Benecke, M. M., \& Osburn, C. D. (2000). Conduct unbecoming; The sixth annual report on "don't ask, don't tell, don't pursue, don't harass." Washington, DC: Servicemembers Legal Defense Network. Available: http://www.sldn.org. (July 22, 2000)

U.S. Congress. (1993). 10 United States code 654. (Pub.L. 103-160 571, 107 Stat., 1547). Washington, DC: U.S. Government Printing Office.

U.S. General Accounting Office. (1993). Homosexuals in the military: Policies and practices of foreign countries (GAO/NSIAD-93-215). Washington, DC: U.S. Government Printing Office.

U.S. Senate. (1993). Policy concerning homosexuality in the armed forces. (Hearings before the Committee on Armed Services, U.S. Senate, 103d Congress, 2d Sess). Washington, DC: U.S. Government Printing Office.

Wenek, K. (1995). Briefing note for director of public policy. Ottawa: Canadian Forces.

Zeeland, S. (1993). Barrack buddies and soldier lovers: Dialogues with gay young men in the U.S. military. New York: Harrington Park Press.

Zeeland, S. (1995). Sailors and sexual identity: Crossing the line between "straight" and "gay" in the U.S. Navy. New York: Harrington Park Press.

Zeeland, S. (1996). Masculine marine: Homoeroticism in the U.S. Marine Corps. New York: Harrington Park Press.

Zeeland, S. (1999). Military trade. New York: Harrington Park Press.

Zuliani, R. A. (1986). Canadian Forces survey on homosexual issues. Ottawa: Department of National Defence. 
